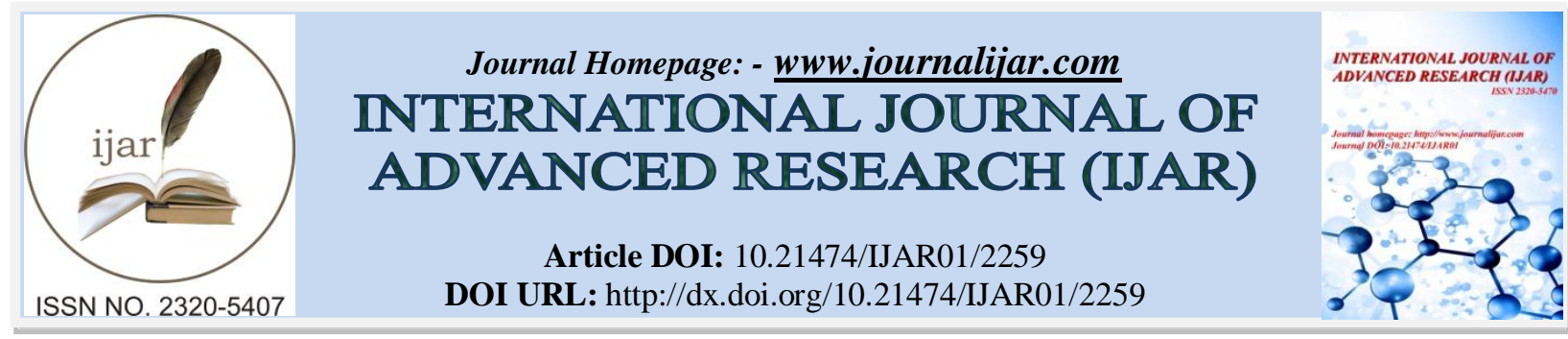

RESEARCH ARTICLE

\title{
ORAL HEALTH STATUS OF FEMALE ORPHANAGE ADOLESCENTS COMPARED TO ADOLESCENTS LIVING WITH THEIR FAMILIES, QASSIM, SAUDI ARABIA.
}

\author{
*Amjad Al-Obaidullah ${ }^{1}$, Bayader Al-Towijiry ${ }^{1}$ and Dr. Khadiga H. Osman ${ }^{2}$. \\ 1. Dental Intern, Qassim University. \\ 2. Assistant professor, Orthodontic and Paediatric Dentistry Department, College of Dentistry, Qassim University.
}

\section{Manuscript Info}

Manuscript History

Received: 29 September 2016

Final Accepted: 30 October 2016

Published: November 2016

Key words:-

Oral health, dental caries orphans,

Orphanage.

\section{Abstract}

Aim: To evaluate the dental health status of female orphans (12-20 years old) living in government orphanages in Qassim, and to compare them with the status of adolescents who live with their families. Materials \& Methods: 30 orphanage girls aged 12-20 in Qassim region (study group) and 30 school girls (comparison group) of same age and area were examined orally for DMFT index and OHI-S after answering a 12-questions questionnaire regarding the oral hygiene practices. Data analysis was done using SPSS. Results: The mean value of the orphan's DMFT (5.27) was found to be higher than nonorphans group (2.03). Moreover, OHI-S showed a higher mean value in orphans (1.40) than their counterparts (0.59). A higher proportion of adolescents 'living with families' (66.7\%) brush their teeth twice daily or more than those living in orphanage. Regarding the type of toothbrush, a significantly higher proportion of orphans (63.3\%) did not know about the type of brush they use. A higher percentage of orphans ( $80 \%$ ) use to change their brush every 3 months compared to their counterparts. A significantly higher proportion of children living with families are attending dentist when in pain $(\mathrm{p}<0.05)$. About one fourth of orphans have never visited a dentist. Conclusion: Oral hygiene practices and index of orphans were found to be worse than the non-orphan group, except for proper time of changing brush. There was a higher score of DMFT among orphans compared with the non-orphan subjects.

Copy Right, IJAR, 2016,. All rights reserved.

\section{Introduction:-}

An orphan is a child who has lost either of his parents or both of them. It is estimated that 153 million of children worldwide, ranging from infants to teenagers, have lost one or both parents. ${ }^{(1)}$ In Islam, orphan's definition is expanded to include children of unknown parentage. The known orphans in Saudi Arabia are usually adopted by their extended families, while the unknown parentages are hosted in government orphanages or by host families under the supervision of the Ministry of Social Affairs. In 2012-2013, government orphanages all over Saudi Arabia reached 18 in number. Only one female governmental orphanage in Qassim province (Unaiza city) hosts children from birth to about 20 years old after which they are shifted to another adults' orphanage. ${ }^{(2)}$ All orphans who live in government orphanages receive social, psychological, medical and educational care. However, dental care is sometimes underestimated. Acquiring information on the dental health status of orphans will help to provide a better 
understanding of the dental health problems of an overlooked segment of the society. It will also help in determining the dental treatment need and hence in planning oral health care services for this population. Many studies have been conducted to investigate the dental health status among children in Saudi Arabia. In one study, caries prevalence was found $96 \%$ of primary school children in Jeddah. ${ }^{(3)}$ In another study conducted in Riyadh's intermediate schools caries prevalence was $93.7 \% .{ }^{(4)}$ However, there are only two published studies that investigated the dental health status of orphans in Saudi Arabia. One in Riyadh conducted on orphans aged 4-12. ${ }^{(5)}$ The other in Jeddah included orphans aged 4-5 years old only. ${ }^{(6)}$ No such study has ever been reported from Qassim province of Saudi Arabia.

The aim of this study was to evaluate the dental health status of female orphans (13-20 years old) living in government orphanage in Qassim, and to compare them with the status of adolescents who live with their families by determining oral hygiene practices, oral hygiene status and prevalence of dental caries.

\section{Materials \& Methods:-}

A descriptive cross-sectional comparative study was conducted in Unaiza city at the government female orphanage (study group), and the girls' government middle and high school in the same region (comparison group). Approval was obtained from the ethical committee of College of Dentistry, Qassim University (code \#: EA/10/2015). Permission was taken from orphanage's administration and schools' principal. Informed consents were obtained from orphans and students above 16 years and parents of school children below or 16 years old. In the orphanage, it was found that orphans from birth to 12 years old are mostly adopted by host families, while those who are older than 12 years were present in the orphanage center (they were 40 in number at the time of this study).

Thirty female orphans were enrolled in the study excluding orphans without permanent stay at the orphanage and those with the age above the selected age group. Thirty school girls living with their families belonging to the same age group and region were randomly selected as a comparison group. A structured multiple-choice questionnaire with 12 questions about demographic data, oral hygiene practices and dental visiting habits was filled by interviewing the study and control groups.

Oral examination for measurement of Decayed-Missing-Filled Teeth Index (DMFT) ${ }^{(7)}$ and Simplified Oral Hygiene IndexOHI-S ${ }^{(8)}$ was done by one examiner under strict infection control procedures using, disposable dental examination kit (plain dental mirror and blunt explorer), gloves, masks and head-light. The data were recorded by one surveyor in a form especially designed for the study. After data collection, oral health education was given for both study groups and all cases that need treatment were referred to dental hospitals / centers.

Data were analyzed using Statistical Package for Social Sciences (SPSS.17). Qualitative data were presented as frequencies and percentages, while quantitative data were presented as means and standard deviations. Chi-square test was used as appropriate to determine the differences between groups. P-value $<0.05$ was considered to be statistically significant.

\section{Results:-}

Results of the study revealed that a higher proportion of non-orphans $(66.7 \%)$ brush their teeth twice or more daily, while $(50 \%)$ of orphans brush only once a day. Regarding the type of toothbrush, $(63.3 \%)$ of orphans did not know about the type of brush they use. Higher percentage of orphans (80\%) change their brush every 1-3 months compared to their counterparts. $33.3 \%$ of orphans have snack more than twice daily compared to (16.7\%) of non orphans. About one fourth of orphans (23.3\%) have never visited a dentist. On the other hand, (63.3\%) of nonorphans are attending dentist when in pain. (Table 1)

Table 1:- Practices of study subjects regarding oral hygiene.

\begin{tabular}{|l|l|l|l|l|l|}
\hline Question & \multicolumn{5}{l}{$\begin{array}{l}\text { 1. How often do your primary care giver or guardians educate you regarding oral hygiene } \\
\text { maintenance? }\end{array}$} \\
\hline & Never & Once & From time to time & Regularly & P-value \\
\hline Orphans & $7(23.3 \%)$ & $5(16.7 \%)$ & $15(50 \%)$ & $3(10 \%)$ & \multirow{2}{*}{ 0.245 } \\
\hline Non orphans & $2(6.7 \%)$ & $4(13.3 \%)$ & $18(60 \%)$ & $6(20 \%)$ & P-value \\
\hline Question & $\mathbf{2 . H o w}$ many times a day do you clean your teeth? & Twice daily or more & $12(40 \%)$ \\
\hline
\end{tabular}




\begin{tabular}{|c|c|c|c|c|c|c|}
\hline Non orphans & $0(0 \%)$ & $10(3$ & $3 \%)$ & $20(6$ & $6.7 \%)$ & 0.050 \\
\hline Question & \multicolumn{6}{|c|}{ 3. What kind of tooth brush do you use? } \\
\hline & $\begin{array}{l}\text { I don't use } \\
\text { tooth brush }\end{array}$ & Soft & \multicolumn{2}{|l|}{ Medium } & I don't know & $P$-value \\
\hline Orphans & $1(3.3 \%)$ & $6(20.0 \%)$ & \multicolumn{2}{|l|}{$4(13.3 \%)$} & $19(63.3 \%)$ & \multirow[b]{2}{*}{$\mathbf{0 . 0 3 5}$} \\
\hline Non orphans & $0(0 \%)$ & $7(23.3 \%)$ & $13(43.3 \%)$ & & $10(33.3 \%)$ & \\
\hline \multirow[t]{2}{*}{ Question } & \multicolumn{6}{|c|}{ 4. How often do you change your tooth brush? } \\
\hline & \multicolumn{2}{|l|}{ 1-3 months } & 6-12 months & \multicolumn{2}{|c|}{ Never change } & $P$-value \\
\hline Orphans & \multicolumn{2}{|l|}{$24(80 \%)$} & $2(6.7 \%)$ & \multicolumn{2}{|c|}{$4(13.3 \%)$} & \multirow[b]{2}{*}{$\mathbf{0 . 0 1 2}$} \\
\hline Non orphans & $18(60.0 \%)$ & & $11(36.7 \%)$ & \multicolumn{2}{|c|}{$1(3.3 \%)$} & \\
\hline \multirow[t]{2}{*}{ Question } & \multicolumn{6}{|c|}{ 5. Do you use dental floss? } \\
\hline & \multicolumn{2}{|l|}{ Yes } & \multicolumn{3}{|l|}{ No } & $P$-value \\
\hline Orphans & \multicolumn{2}{|l|}{$8(26.7 \%)$} & & \multirow[b]{2}{*}{0.206} \\
\hline Non orphans & \multicolumn{2}{|l|}{$12(40 \%)$} & \multicolumn{3}{|l|}{$\frac{22(15.3 \%)}{18(60 \%)}$} & \\
\hline \multirow[t]{2}{*}{ Question } & \multicolumn{6}{|c|}{ 6. What type of food do you take more in your diet? } \\
\hline & Vegetables & Meat & Diary prod & & $\begin{array}{ll}\text { Sweets } & \text { and } \\
\text { Starches } & \end{array}$ & P-value \\
\hline Orphans & $4(13.3 \%)$ & $1(3.3 \%)$ & $2(6.7 \%)$ & & $23(76.7 \%)$ & \\
\hline Non orphans & $8(26.7 \%)$ & $3(10 \%)$ & $4(13.3 \%)$ & & $15(50 \%)$ & 0.196 \\
\hline Question & 7. How often $d$ & you snack? & & & & \\
\hline & Occasionally & Once daily & Twice daily & & $\begin{array}{l}\text { More than twice } \\
\text { daily }\end{array}$ & P-value \\
\hline Orphans & $3(10 \%)$ & $13(43.3 \%)$ & $4(13.3 \%)$ & & $10(33.3 \%)$ & \\
\hline Non orphans & $2(6.7 \%)$ & $9(30 \%)$ & $14(46.7 \%)$ & & $5(16.7 \%)$ & 0.043 \\
\hline Question & 8. What is you & snack type usu & lly? & & & \\
\hline & $\begin{array}{l}\text { Chocolate \& } \\
\text { sweets }\end{array}$ & Chips & Nuts & & $\begin{array}{l}\text { Ice cream \& } \\
\text { beverages }\end{array}$ & $P$-value \\
\hline Orphans & $11(36.7 \%)$ & $11(36.7 \%)$ & $2(6.7 \%)$ & & $6(20.0 \%)$ & \\
\hline Non orphans & $12(40 \%)$ & $10(33.3 \%)$ & $3(10 \%)$ & & $5(16.7 \%)$ & 0.944 \\
\hline Question & 9. When do yo & visit a dentist? & & & & \\
\hline & $\begin{array}{l}\text { For regular } \\
\text { checkup }\end{array}$ & $\begin{array}{l}\text { In presence } \\
\text { of pain }\end{array}$ & $\begin{array}{l}\text { If } \quad \text { I } \\
\text { appointment }\end{array}$ & have & never & P-value \\
\hline Orphans & $1(3.3 \%)$ & $10(33.3 \%)$ & $12(40 \%)$ & & $7(23.3 \%)$ & \\
\hline Non orphans & $2(6.7 \%)$ & $19(63.3 \%)$ & $9(30 \%)$ & & $0(0 \%)$ & 0.014 \\
\hline Question & $\begin{array}{l}\text { 10. Do you vis } \\
\text { guardian? }\end{array}$ & the dentist by & your own des & re or & the desire of you & $r$ care giver or \\
\hline & Self desire & & Someone & else & & P-value \\
\hline Orphans & $24(80 \%)$ & & $6(20 \%)$ & & & \\
\hline Non orphans & $24(80 \%)$ & & $6(20 \%)$ & & & 0.626 \\
\hline
\end{tabular}

Table (1) shows that 5 of the 10 questions regarding oral hygiene practices exhibited statistically significant difference between orphans and non-orphans.

Table (2): DMFT scores for the study and comparison groups

\begin{tabular}{|l|l|l|l|}
\hline Social status & $\begin{array}{l}\text { Debris } \\
\text { Mean } \pm \text { SD }\end{array}$ & $\begin{array}{l}\text { Calculus } \\
\text { Mean } \pm \text { SD }\end{array}$ & $\begin{array}{l}\text { OHI-S } \\
\text { Mean } \pm \text { SD }\end{array}$ \\
\hline Orphans & $.94 \pm .44$ & $.47 \pm . .33$ & $1.4 \pm .59$ \\
\hline Non orphans & $.47 \pm .27$ & $.13 \pm .23$ & $.59 \pm .39$ \\
\hline & P-value & 0.00 & 0.00 \\
\cline { 2 - 3 } & 0.00 & \multicolumn{2}{|l|}{} \\
\hline
\end{tabular}

Table (2) shows that the mean DMFT scores were higher among orphans with significant difference in the decayed teeth. 
Table 3:- OHI-S scores for the study and comparison groups

\begin{tabular}{|c|c|c|c|c|}
\hline $\begin{array}{ll} & \text { Social } \\
\text { status } & \\
\end{array}$ & $\begin{array}{ll}\text { Decayed } & \text { teeth } \\
\text { Mean } \pm \text { SD } & \\
\end{array}$ & $\begin{array}{ll}\text { Missing } & \text { Teeth } \\
\text { Mean } \pm \text { SD } & \\
\end{array}$ & $\begin{array}{ll}\text { Filled } & \text { teeth } \\
\text { Mean } \pm \text { SD } & \end{array}$ & $\begin{array}{l}\text { DMFT } \\
\text { Mean } \pm \text { SD }\end{array}$ \\
\hline Orphans & $4.23 \pm 3.636$ & $.17 \pm .531$ & $.87 \pm 1.479$ & $5.27 \pm 3.947$ \\
\hline Non orphans & $.90 \pm 1.094$ & $.23 \pm .679$ & $.90 \pm 1.398$ & $2.03 \pm 2.025$ \\
\hline & \multicolumn{4}{|l|}{$P$-value } \\
\hline & 0.00 & 0.673 & 0.929 & 0.00 \\
\hline
\end{tabular}

Table (3) shows that the mean OHI-S scores were higher among orphans. The scores were all significantly different between the 2 groups

Figure (1): Distribution of study subjects according to the oral health status

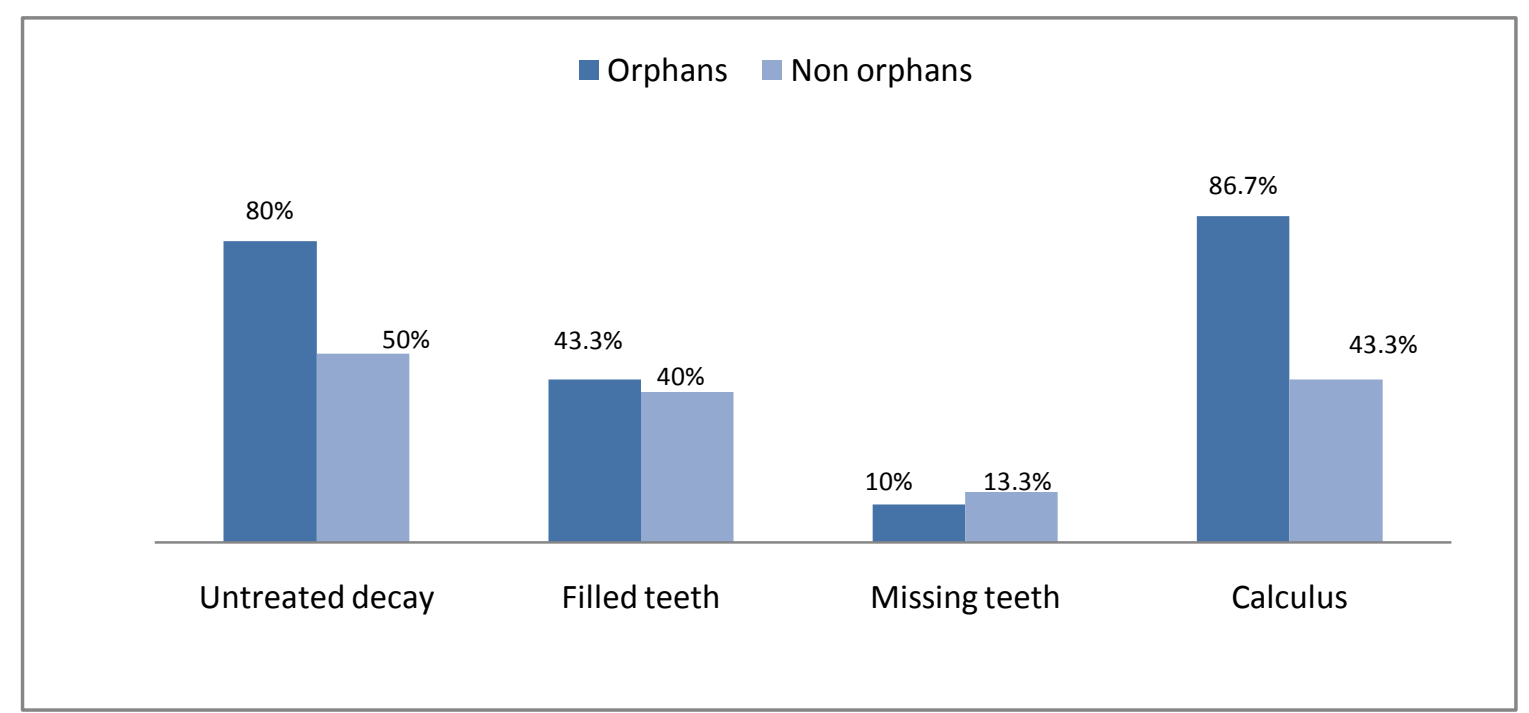

Figure (1) shows that higher percentage of orphans (80\%) has untreated decay as compared to their fellows. In addition, higher percentages of orphans $(86.7 \%)$ are having calculus and require scaling of teeth.

\section{Discussion:-}

Present study was conducted to assess the oral health status and practice among orphanage adolescents in comparison to non orphans. Our results cannot be generalized to the entire orphanage in Saudi Arabia because of the diverse culture, food pattern, geographic location, and other factors like delivered care by their administrations. In addition, orphans from birth up to 12 years of age are mostly adopted.

In this study, (50\%) of orphans stated that the orphanage educate them from time to time about the oral health. However, a previous study in India ${ }^{(9)}$ showed that $82.5 \%$ of children did not receive appropriate information. A high statistically significant difference was found between the orphans and comparison group in regards to the frequency of brushing. About (67\%) of non-orphans brush twice daily or more whilst $(50 \%)$ of orphans are once daily brushers. Shanbhog, et al. ${ }^{(9)}$ reported in their study that it is compulsory for the orphans to brush twice daily there. Surprisingly, it was found that $(80 \%)$ of the orphans in the present study had the habit of changing their toothbrush within 1-3 months. This could be related to the supplies the orphans get for free from the government. Contradictory results were found ${ }^{(10)}$ in which $70 \%$ of the orphans change their toothbrush within longer period of time which is every 6 months.

Higher percentages of orphans and non orphans were not using dental floss. This comes in accord with the findings of earlier studies ${ }^{(11,12)}$. In contrast with the finding in San Francisco ${ }^{(13)}$, where $75 \%$ of the students used dental floss at least once a day.

Almost $44 \%$ of orphans were found to snack once daily. About $47 \%$ of non orphans were found to snack twice daily. Both groups consumed chocolate, sweets and chips. This finding of the study was in agreement with the 
study carried out by Lonim Prasai Dixit et al. ${ }^{(14)}$, in Nepal in which $75 \%$ of the children consumed sugar rich foods once daily.

There were only $3.3 \%$ of orphans who visited a dentist for regular checkups, $40 \%$ visited the dentist if they have an appointment and about one fourth of orphans (23.3\%) have never visited a dentist in their life time. A higher percentage of the comparison group visited the dentist as compared to the orphan group where they might have received advice on preventive oral health care and instructions on how to brush their teeth properly. So, this could be one of the reasons of low caries scores found in orphans.

\section{Conclusion:-}

1-Oral hygiene practices of orphans were worse than the non-orphan group, except for changing the tooth brush in which a significantly higher percentage of orphans are changing brush every 1-3 months.

2-Orphans had significantly higher DMFT score than non-orphans.

3-The orphan group had worse oral hygiene compared to the other group.

\section{Limitations and Recommendations:}

The sample was small because of lack of cooperation from some orphans, difficult access to the male orphans due to community mores and family adoption of most of orphans from birth until age 12 .

We recommend further studies to include male orphans and orphans in other provinces. And to compare their oral health status with non-orphans in the region and look for causes and solve them. Most important point is the implementation of oral health education programs in orphanages as well as in schools. Also we recommend that each orphanage include dental clinic with complete dental team to increase awareness and oral health education, follow up and perform needed dental treatment for orphans.

\section{Acknowledgments:-}

We would like to thank Dr. Abdul Haleem Hameed for his great help and effort in data analysis.

Great appreciation to the cooperation we got from orphanage school administrator and the participants.

\section{References:-}

1. http://www.unicef.org.

2. http://www.mosa.gov.sa/sites/default/files/uploads/Statistical\%20Year\%20book.pdf.

3. Al-Malik M, Rebini Y. prevalence of dental caries, severity, and pattern in age 6 to 7-Year-old children in selected community in Saudi Arabia. J Contemp Dent Pract 2006; 7(2);46-54

4. Al-Sadhan S. Dental caries prevalence among 12-14 year-old schoolchildren in Riyadh: A 14 year follow-up study of the Oral Health Survey of Saudi Arabia. Saudi Dental J 2006; 18(1): 2-7

5. Al-Jobair A, Al-Sadhan S, et al. Medical and dental health status of orphan children in central Saudi Arabia. Saudi Med J 2013; 34(5): 531-36.

6. Al-Malik M, Holt R. The prevalence of caries and of tooth tissue loss in a group of children living in a social welfare institute in Jeddah, Saudi Arabia. Int Dent J 2000; 50: 289-292.

7. World Health Organization. Oral Health Surveys: Basic Methods; 4th ed 1997.

8. John G. Greene, Jack R. Vermillion. The Simplified Oral Hygiene Index. JADA 1964; 68(1): 7-13.

9. Shanbhog R, Raju V, Nandlal B. Correlation of oral health status of socially handicapped children with their oral heath knowledge, attitude, and practices from India. J Nat ScBiol Med 2014;5:101-7.

10. Hans R et al. Oral Health Knowledge, Attitude and Practices of Children and Adolescents of Orphanages in Jodhpur City Rajasthan, India. Journal of Clinical and Diagnostic Research. 2014; 8(10): 22-25

11. Sushanth VH, Krishna M, Suresh Babu AM, Prashant GM, Chandu GN. A peergroup approach model of oral health promotion among orphans at Puduchery,South India. J IntSocPrevComm Dent. 2011;1(2):71-75. Khare V, Koshy A, Rani P, Srilatha S, Kapse SC, Aggarwal A. Prevalence ofDental Caries and Treatment Needs among the orphan children and adolescentsof Udaipur district, Rajasthan, India. J Contemp Dent Pract.2012;13(2):182-87.

Russel BA, Horowitz AM, Frazier PJ. School-based preventive regiments and oral health knowledge and practices of sixth graders. J Public Health Dent 1989;49:192-200.

12. Prasai Dixit L, Shakya A, Shrestha M, Shrestha A. Dental caries prevalence, oral health knowledge and practice among indigenous Chepang school children of Nepal. BMC Oral Health. 2013;13:20. 
13. Al-Maweri SA, Al-Soneidar WA, et al. Oral lesions and dental status among institutionalized orphans in Yemen: A matched case-control study. ContempClin Dent 2014; 5:81-84.

14. Camacho GA, Camacho E, et al. Predisposing factors for dental caries in girls at an orphanage of Mexico. ActaPediatrMex 2009; 30: 71-76.

15. Kumar S, Goyal A, et al. Oral health related quality of life among children with parents and those with no parents. Community Dent Health 2011; 28: 227-231. 